\title{
The Bronze Age battlefield in the Tollense Valley - conflict archaeology and Holocene landscape reconstruction
}

\author{
Gundula Lidke and Sebastian Lorenz \\ University of Greifswald, Institute of Geography and Geology, Friedrich-Ludwig-Jahn-Straße 16, \\ 17487 Greifswald, Germany
}

Correspondence: Gundula Lidke (tollensetal-projekt@web.de)

Relevant dates: $\quad$ Published: 15 August 2019

How to cite: Lidke, G. and Lorenz, S.: The Bronze Age battlefield in the Tollense Valley - conflict archaeology and Holocene landscape reconstruction, DEUQUA Spec. Pub., 2, 69-75, https://doi.org/10.5194/deuquasp-2-69-2019, 2019.

Abstract:

\begin{abstract}
Archaeological discoveries in the Tollense Valley represent remains of a Bronze Age battle of ca. 1300-1250 BCE, documenting a violent group conflict hitherto unimagined for this period of time in Europe, changing the perception of the Bronze Age. Geoscientific, geoarchaeological and palaeobotanical investigations have reconstructed a tree- and shrubless mire characterised by sedges, reed and semiaquatic conditions with a shallow but wide river Tollense for the Bronze Age. The exact river course cannot be reconstructed, but the distribution of fluvial deposits traces only a narrow corridor, in which the Tollense meandered close to the current riverbed. The initial formation of the valley mire dates to the transition from the Weichselian Late Glacial to the early Holocene.
\end{abstract}

\section{Introduction and history of archaeological research}

The valley of the river Tollense in Mecklenburg-Western Pomerania (northeastern Germany, 53 $44^{\prime} 53.25^{\prime \prime} \mathrm{N}$, $13^{\circ} 18^{\prime} 19.84^{\prime \prime}$ E, Fig. 1a) was the scene of dramatic events sometime during the first half of the 13th century BCE. Following chance finds in the riverbank by an amateur archaeologist in 1996 - among them, a human upper arm bone with embedded flint arrowhead and a wooden club - first trial excavation in the same year revealed a find layer close to the river with disarticulated skeletal remains, mostly human, some horse. A burial context could be excluded as there were neither related structures nor grave goods; in contrast even more indications for violence were detected, such as a skull with a large depressed fracture. The extraordinary find area has been the subject of intensive multidisciplinary research since 2009 (Jantzen et al., 2011,
2014). Skeletal remains of more than 130 individuals, likely all men, many of them evidently killed in violent conflict, are preserved at various sites in the valley; there are also all kinds of weaponry, ranging from bronze and flint arrowheads to now several wooden clubs and bronze weapons, such as a sword, spearheads and knives. The finds together attest a violent armed clash with at least several hundred (possibly thousands) participants, a conflict of a scale hitherto unexpected for the European Bronze Age. The neighbouring locations, i.e. the numerous archaeological sites representing the conflict, presumingly indicate different situations of deposition and implementation in sedimentary environments.

\section{Archaeology in the river valley}

Finds are spread over a stretch of the river more than $3 \mathrm{~km}$ long (Fig. 1b). They occur in different circumstances and 


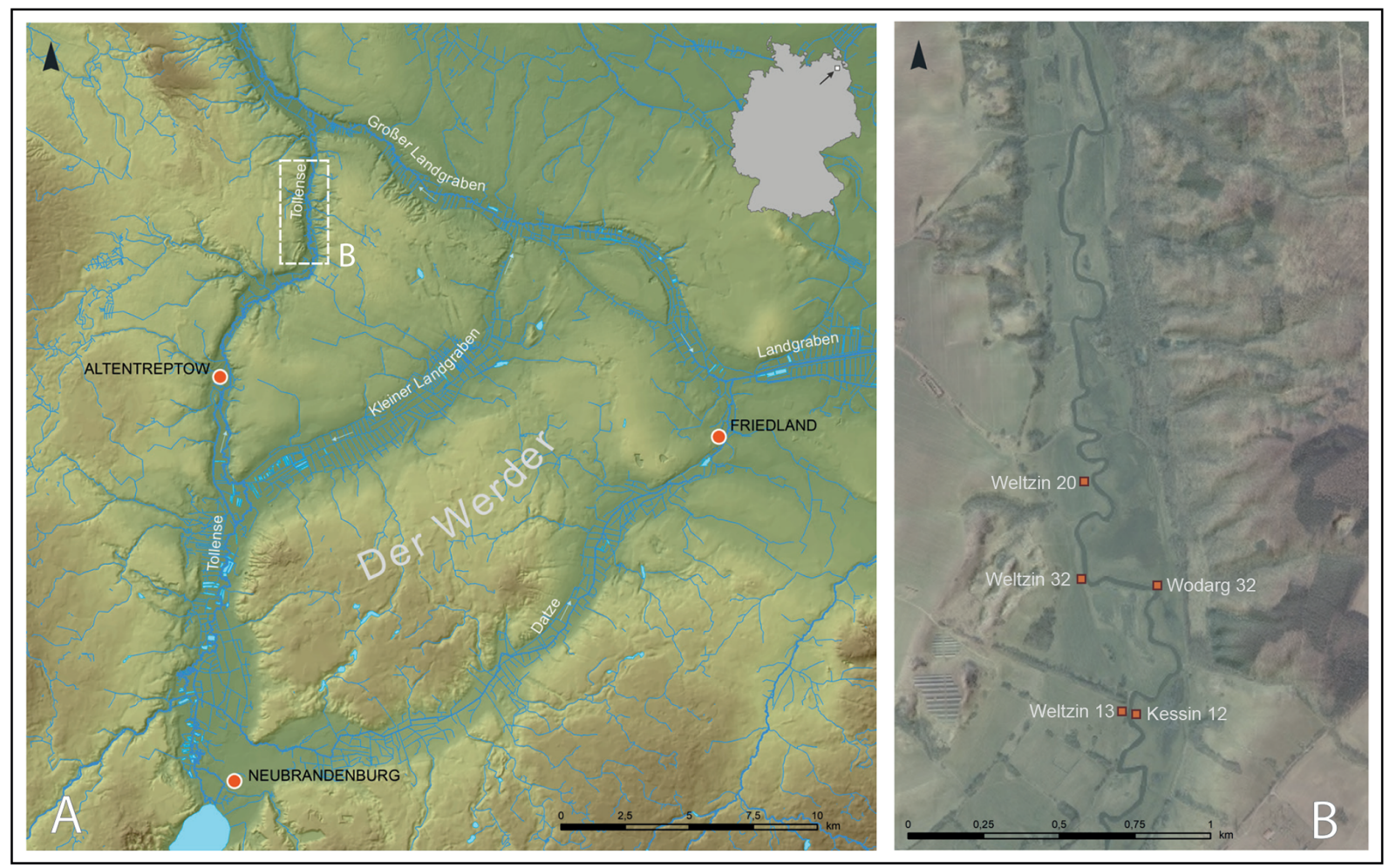

Figure 1. General shaded relief map with drainage system topography (A) and the location of the archaeological sites related to the conflict scenario (B). Based on data from @GeoBasis-DE/M-V 2016.

include mostly skeletal remains, but also weapons made of bronze, flint and wood. In situ finds, covered by a peat layer, can be found close to the river on the adjacent meadows as well as in riverbank sections exposed by erosional river dynamics. Furthermore, during dredging works in the 1970s and 1980s - to deepen the riverbed and to drain the mire sediments including find material were taken out of the river and dispersed on the adjacent meadows, where skeletal remains and bronze objects can now be discovered displaced in secondary positions.

The most definite concentrations of human skeletal remains and weapon finds occur between sites Weltzin 13Kessin 12 to the south and Weltzin 20 to the north (Terberger et al., 2014b). Nearly continuous find layers with human skeletal remains were documented there in sections of the riverbanks during diving surveys. Find intensity is especially high between sites Weltzin 32 and 20; in both areas in situ finds as well as finds from secondary contexts are documented. Further north of Weltzin 20 mostly dispersed skeletal remains have been discovered so far. Bones and remains of wooden shafts of arrows from several sites have been dated with accelerator mass spectrometry to ca. 13001250 BCE. These results together with the similarity of the sites and their find material, the state of preservation of the skeletal remains, the patterns of lesions, and the distribution of weapon finds indicate that all sites represent remains of one major conflict rather than several repeated minor ones (Terberger et al., 2018).

\section{A causeway to conflict?}

Sites Kessin 12 and Weltzin 13 represent the starting point of the "battlefield horizon" layer with human skeletal remains, partly with lesions, and bronze arrowheads. But finds from the Neolithic to the Middle Ages indicate that this area of the valley was - due to a favourable position in the valley layout - used as a river and valley crossing for several millennia (Jantzen et al., 2014). During diving surveys, remains of wooden constructions were detected in the eastern riverbank, dating to ca. $1300 \mathrm{BCE}$, indicating the use of the crossing during the time of the conflict, too. Geophysical measurements in the eastern floodplain showed linear structures over ca. $100 \mathrm{~m}$, which during excavation turned out to be remains of a stone-flanked causeway built with wood, sand and turf at ca. 1900 BCE. This causeway (Fig. 2) likely made the crossing of the wet and at times possibly swampy floodplain possible during all seasons. Horse teeth discovered directly on the surface of the causeway were dated to ca. 1300 BCE again, indicating that this crossing was still known and used hundreds of years after its construction. Likely the causeway and valley crossing were the starting point of the conflict (Jantzen et al., 2014). 

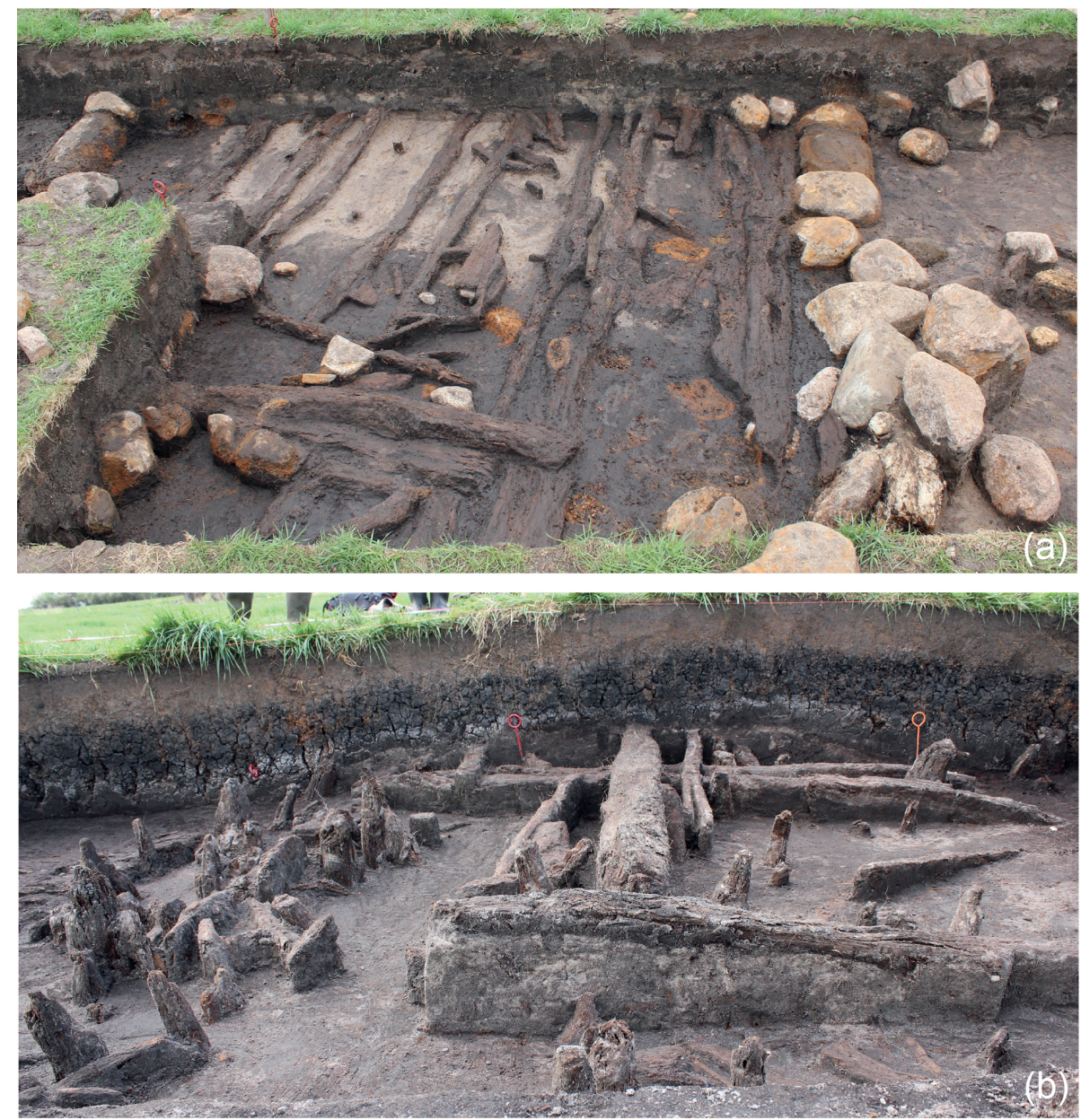

Figure 2. Kessin 12. Causeway with different methods of construction. (a) Stone-flanked causeway, excavated in 2013. (b) Causeway built with wood, sand and turf, excavated in 2014. Photos: Gundula Lidke.

\section{Dead bodies in the river}

At site Weltzin 32 the in situ find layer is situated ca. 2$3 \mathrm{~m}$ below the present surface in fluviatile sediments, likely those of the Bronze Age river. Extensive diving surveys have shown a continuous skeletal find layer over more than $60 \mathrm{~m}$ in the western river bank; there are also skeletal remains in the eastern river bank. Due to the depth of the in situ find layer only limited excavations on land have taken place so far. Interestingly, valuable finds like a gold spiral ring, two tin rings and four small bronze spirals were discovered in the find layer here, too. These are interpreted as personal belongings of combatants that could not be looted after battle due to the position of the bodies in the river (Krüger et al., 2012). A high number of bronze socketed arrowheads are attested here from the sediments displaced by dredging; one flint arrowhead stems from the in situ find layer in the riverbank section. The human bones show several perimortem lesions that originate from close as well as long-range weapons. Together, the finds indicate that fighting took place at this site.
According to a hypothetical scenario (Lidke et al., 2018), the fighting might have moved northward from the causeway in a "running battle", with skirmishes and heavy fighting along the way.

\section{$5 \quad$ A last stand and heavy casualties?}

A little to the north, site Weltzin 20 is situated on an alluvial fan in the Tollense Valley. Here the in situ find layer is documented at ca. $0.8-1.7 \mathrm{~m}$ below the present surface. Taking off from the trenches of the 1996 excavation, which itself took place around the spot where the first discoveries had been made, ca. $460 \mathrm{~m}^{2}$ had been excavated until 2015. More than 10000 human remains, mostly found disarticulated, are documented from this site alone, partly in dense clusters, partly isolated (Fig. 3). In some cases there are horse bones, also disarticulated, indicating that these animals were involved in the conflict, too. Further finds within the skeletal find layer are very sparse and consist mostly of flint and bronze arrowheads; furthermore, there is just one bronze finger ring and a 


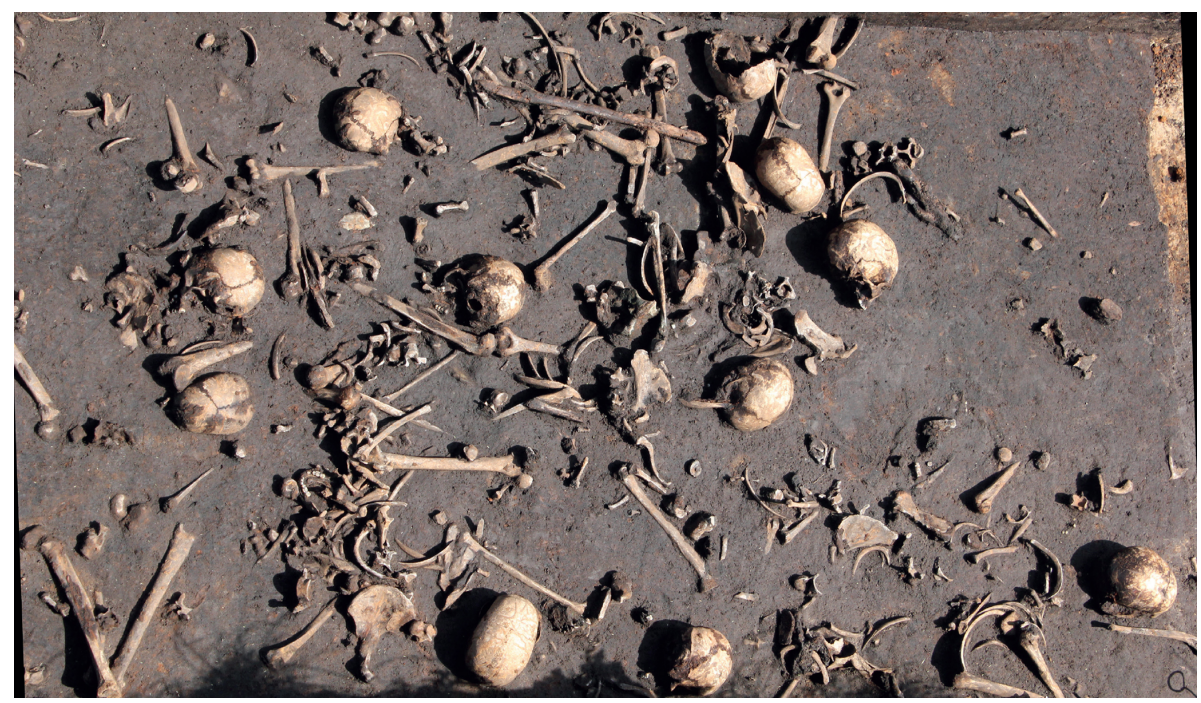

Figure 3. Weltzin 20. Find layer with disarticulated human remains under excavation in 2013. Photo: Jana Dräger.

bone pin. More bronze socketed arrowheads were discovered during metal detecting in sediments displaced by dredging. According to the hypothetical scenario (Lidke et al., 2018), this site might have seen heavy fighting with a high number of casualties. The human bones again show a greater number of perimortem lesions, caused by close as well as long-range weapons, e.g. lesions by arrow shot; stabbing and cutting wounds perhaps caused by swords, knives or spearheads; and blunt traumata, probably caused by clubs or other blunt objects. The absence of other finds - apart from the few small objects mentioned above - indicates that the dead were looted thoroughly here.

\section{Human skeletal remains and weapon lesions}

More than 12000 human skeletal remains are known from several sites in the Tollense Valley. Most of them stem from site Weltzin 20 where the most extensive research has taken place so far. More than 140 individuals can be reconstructed, most of them young adult males. A large number of bones show perimortem lesions, mostly caused by sharp force trauma, including arrowhead wounds as well as stabbing and cutting wounds. Blunt force lesions occur in lower numbers. There are also healed lesions, some of which stem from weapon use, which indicate that some individuals had also encountered violence in previous situations (Brinker et al., 2018). Analyses of aDNA and isotopes ( $\mathrm{Sr}, \mathrm{C}, \mathrm{N}$ ) point to a heterogeneous population group (Terberger and Heinemeier, 2014a; Price et al., 2017). Calculating from the number of the dead in the valley at least hundreds of battle participants are likely, representing a not purely local population. All in all, the remains of the conflict in the Tollense Valley help to draw a new picture of the European Bronze Age society.

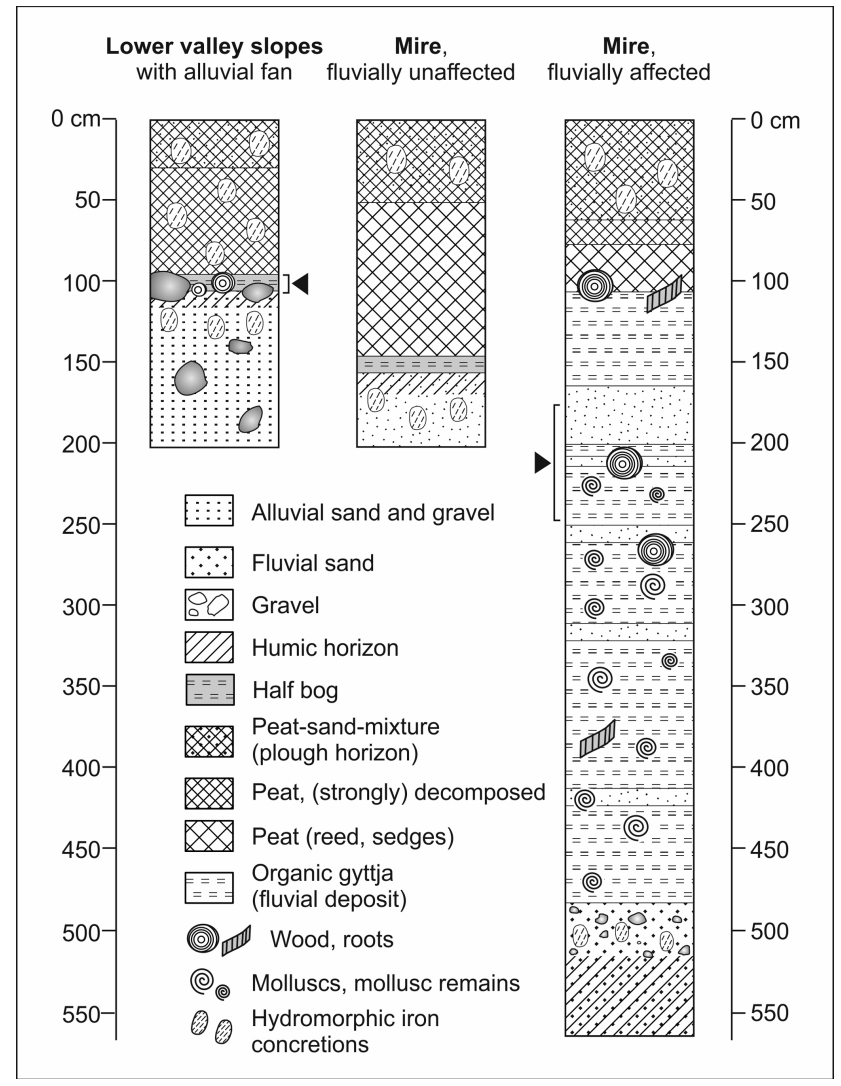

Figure 4. Standard profiles from the Tollense Valley near Weltzin (adapted from Lorenz et al., 2014). 


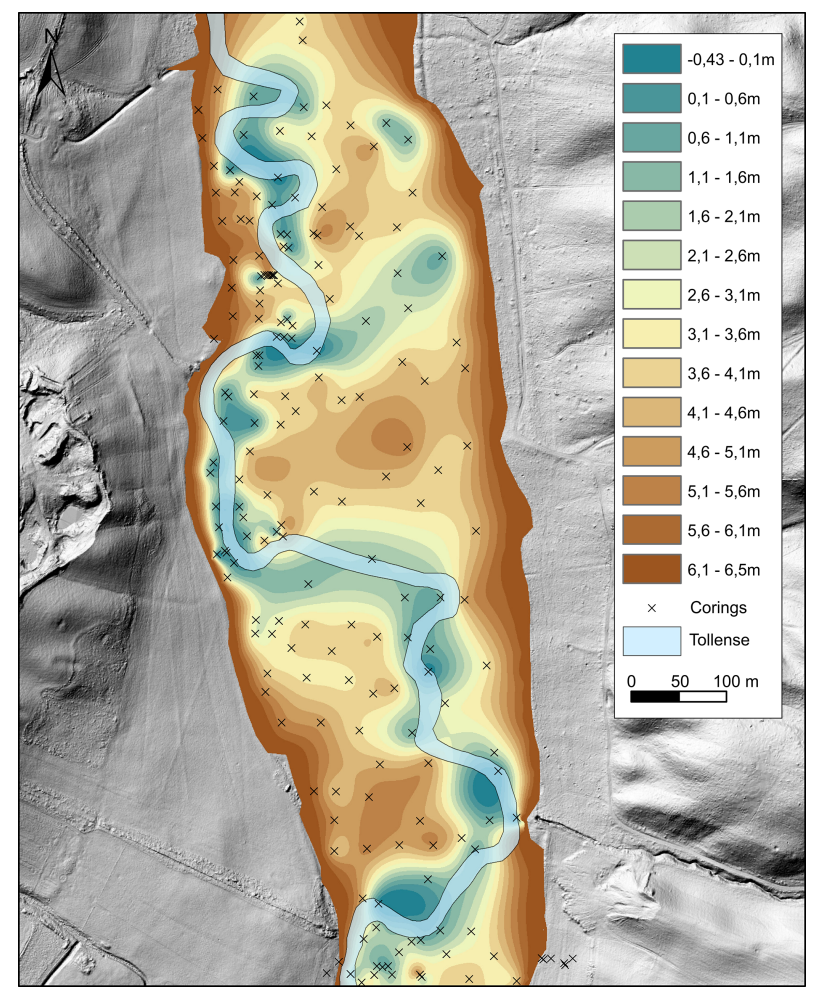

Figure 5. The minerogenic valley ground with incised palaeochannel derived from corings (adapted from Lorenz et al., 2014). Elevations are given in metres above sea level (m a.s.l.).

\section{Weichselian Late Glacial to Holocene valley formation}

The river Tollense, which is today $5-15 \mathrm{~m}$ wide and up to $4 \mathrm{~m}$ deep, flows in a $250-400 \mathrm{~m}$ wide incised valley of subglacial origin. The development of vast mires during the Holocene in the low river valleys south to the Baltic Sea was firstly associated with the rising Littorina Sea by Keilhack (1898). The current state of knowledge on the postglacial development of coastal river valleys and its mires has been comprehensively framed by Janke (2002, 1978), distinguishing 10 phases of valley formation from the deglaciation of the Mecklenburg Phase to the present (Börner et al., 2012, pp. 292-296). The valley of the river Tollense between Weltzin and its confluence with the river Peene in Demmin has been investigated with more than 250 corings and soil logs to reconstruct the Holocene palaeoenvironment with a special focus on the $1.5 \mathrm{~km}$ river course around the Bronze Age battlefield (Lorenz et al., 2014).

The Pleistocene ground of the valley consists of glaciofluvial sands and gravels. During the Pleniglacial and Preboreal/Boreal, deep gullies were fluvially eroded and subsequently filled with organic gyttjas and sand, rich in molluscs. Outside the gullies, the Pleistocene valley ground does not show a uniform gradient. In the Tollense Valley between Demmin and Weltzin the start of the limnic or organic sedi- mentation occurred from the Weichselian Late Glacial to Preboreal period (Lorenz et al., 2014, ca. 10300-12500 cal BP) and is therefore completely independent of the Baltic Sea level, which was at this time more than $15 \mathrm{~m}$ below (Lampe, 2005). A preferred direction of the onset of sedimentation against or along the decline of the valley is not recognisable. Furthermore no influence of the backlog caused by the Littorina transgression (Richter, 1968; Michaelis and Joosten, 2007) could be detected. The stratigraphies within the mire can be described as three standard profiles (Fig. 4): (1) alluvial fans, (2) fluvially influenced mire and (3) fluvially unaffected mire. Each has a decomposed peat at the surface, severely degraded by drainage and bearing iron concretions down to ca. $70 \mathrm{~cm}$. Dumping of dredging materials from the river and ploughing in the recent past have also disrupted the mire surface.

The alluvial fans consist of morainic debris and belong to large gullies in the valley slopes, which were mainly created under periglacial conditions, but were fossilised with the onset of the Holocene and have been reshaped by colluvial sediments since the Subboreal. At some places, the alluvial fans narrow the valley and influence the river's course. This is the case for site Weltzin 20, where the surface of an alluvial fan with superimposed peat layers was excavated.

The fluvially unaffected mire is represented by peats of reed and sedges, which were initially formed by drowning, and then subsequently grew up with the rising groundwater table, overprinted by episodic floods of the river. This is indicated in particular by the absence of molluscs and minerogenic layers. Wood remains were rarely found in peat. At depths between 150 and $200 \mathrm{~cm}$, the peat is underlain by buried humic gleyic soil. In contrast, the areas affected by fluvial sedimentation show no exclusive peat stratigraphy but interbedding with fluvial sands and organic gyttjas with numerous wooden remains and molluscs underneath a strongly decomposed peat. The alternating sequences reach thicknesses up to $4 \mathrm{~m}$ and represent deposits of slowly flowing to stagnant water. These sediments comprise many records of natural driftwood, but also artificial piles, wooden structures and fish fences, dating not only to the Bronze Age.

The reconstructed minerogenic valley ground reveals a $50-200 \mathrm{~m}$ wide channel, which is at least $2 \mathrm{~m}$ incised in the valley floor (Fig. 5). It runs in large meander loops, while a slope to the north or south cannot be derived. This structure is interpreted as a Weichselian Late Glacial riverbed, which can be attributed to the Dryas phases (Janke, 1978; Börner et al., 2012). The occurrence of the younger fluvial deposits is limited to this former riverbed, and today's river Tollense runs with smaller meanders within these boundaries (Fig. 5). The Weichselian Late Glacial riverbed has evidently been inherited and traced throughout the Holocene; younger river courses other than that channel are not recognisable. 
The Bronze Age find layers in the Tollense Valley differ in depth and sedimentological composition, but are always connected to fluvial sediments and their distribution of the former riverbed, which has been relocated in the last 3000 years only to a small extent. In addition to the interpretation of sedimentological parameters, analyses of botanical remains, wood species identification and pollen analyses were carried out to reconstruct the Bronze Age environment. Sediments and microfossils indicate clear differences in groundwater level and vegetation between the Bronze Age environment and the present-day appearance of the landscape (Lorenz et al., 2014).

The river Tollense is considered to have formed a shallower, and presumably broader, riverbed for this period. The close proximity of sands and organic deposits suggests fluctuating but generally lower flow velocities. The river was overgrown with aquatic plants and only the respective current line transported sands. The mire surface at that time was still about $1 \mathrm{~m}$ lower, so the alluvial fans clearly outlined into the valley. During floods, they were obstacles where floating debris accumulated like proposed for site Weltzin 20, where numerous skeletal remains and wooden material have been excavated. Due to rearrangements by the fluctuating run-off, wooden branches and skeletal remains remained in the (semi)aquatic environment, were subsequently covered by sediments and conserved or rearranged on a small scale along the river banks. During the Bronze Age, the Tollense Valley was dominated by vast Carex reeds with open water surfaces. Today's meadows exist on meliorated and degraded peatlands that are extensively used for agriculture. In comparison, the hydraulic configuration of the river also stands in strong contrast. Today the river Tollense is strongly incised into the surrounding peatlands, due to straightening and shortening of the river course, as well as by annual river maintenance with the clearing and partly dredging of the riverbed. Increased flow velocities cause very steep embankments and the formation of a trough-like channel.

Data availability. Geological data can be requested from the authors.

Author contributions. GL and SL wrote the paper and prepared all figures.

Competing interests. The authors declare that they have no conflict of interest.

Acknowledgements. The research in the Tollense Valley and the results presented here involve a large number of people whom we would like to thank in this regard. We further acknowledge support for the Tollense Valley project from the German Research Foundation between 2010 and 2017 (DFG, nos. JA 1835/2 and TE 258/8). We would also like to thank the anonymous reviewer for helpful comments on the manuscript. We acknowledge support for the article processing charge from the DFG (no. 393148499) and the Open Access Publication Fund of the University of Greifswald.

Financial support. This research has been supported by the DFG (German Research Foundation, grant no. 393148499) and the Open Access Publication Fund of the University of Greifswald.

\section{References}

Brinker, U., Harten-Buga, H., Staude, A., Jantzen, D., and Orschiedt, J.: Prehistoric Warfare and Violence, chap. Perimortem Lesions on Human Bones from the Bronze Age Battlefield in the Tollense Valley: An Interdisciplinary Approach, 39-60, Springer International Publishing, Cham, https://doi.org/10.1007/978-3-319-78828-9_3, 2018.

Börner, A., Janke, W., Lorenz, S., Pisarska-Jamroży, M., and Rother, H.: Das Jungquartär im Binnenland MecklenburgVorpommerns - glaziale Morphologie, Gewässernetzentwicklung und holozäne Landnutzungsgeschichte, in: Jahresberichte und Mitteilungen des Oberrheinischen Geologischen Vereins, N.F., 94, 287-313, 2012.

Janke, W.: Schema der spät- und postglazialen Entwicklung der Talungen der spätglazialen Haffstausee-Abflüsse, Wissenschaftliche Zeitschrift der Ernst-Moritz-Arndt-Universität Greifswald, Mathematisch-naturwissenschaftliche Reihe, 27, 39-43, 1978.

Janke, W.: The development of the river valleys from the Uecker to the Warnow, Greifswalder Geographische Arbeiten, 31, 101106, 2002.

Jantzen, D., Brinker, U., Orschiedt, J., Heinemeier, J., Piek, J., Hauenstein, K., Krüger, J., Lidke, G., Lübke, H., Lampe, R., Lorenz, S., Schult, M., and Terberger, T.: A Bronze Age battlefield? Weapons and trauma in the Tollense Valley, north-eastern Germany, Antiquity, 85, 417-433, https://doi.org/10.1017/S0003598X00067843, 2011.

Jantzen, D., Lidke, G., Dräger, J., Krüger, J., Rassmann, K., Lorenz, S., and Terberger, T.: An early Bronze Age causeway in the Tollense Valley, Mecklenburg-Western Pomerania - The starting point of a violent conflict 3300 years ago?, Bericht der Römisch-Germanischen Kommission, 95, 13-49, https://doi.org/10.11588/berrgk.2017.0.44423, 2014.

Keilhack, K.: Die Entwicklung der glazialen Hydrographie Norddeutschlands, Zeitschrift der deutschen Geologischen Gesellschaft, 50, 77-83, 1898.

Krüger, J., Nagel, F., Nagel, S., Jantzen, D., Lampe, R., Dräger, J., Lidke, G., Mecking, O., Schüler, T., and Terberger, T.: Bronze Age tin rings from the Tollense valley in Northeastern Germany, Praehist. Z., 87, 29-43, https://doi.org/10.1515/pz-2012-0002, 2012.

Lampe, R.: Lateglacial and Holocene water-level variations along the NE German Baltic Sea coast: review and new results, Quatern. Int., 133, 121-136, 2005. 
Lidke, G., Jantzen, D., Lorenz, S., and Terberger, T.: The Bronze Age battlefield in the Tollense Valley, Northeast Germany: conflict scenario research, in: Conflict archaeology: Materialities of collective violence in late prehistoric and early historic Europe, edited by: Fernández-Götz, M. and Roymans, N., vol. 5 of Themes in Contemporary Archaeology, 61-68, 2018.

Lorenz, S., Schult, M., Lampe, R., Spangenberg, A., Michaelis, D., Meyer, H., Hensel, R., and Hartleib, J.: Geowissenschaftliche und paläoökologische Ergebnisse zur holozänen Entwicklung des Tollensetals, in: Tod im Tollensetal - Forschungen zu den Hinterlassenschaften eines bronzezeitlichen Gewaltkonfliktes in Mecklenburg-Vorpommern, edited by: Jantzen, D., Orschiedt, J., Piek, J., and Terberger, T., vol. 50 of Beiträge zur Ur- und Frühgeschichte Mecklenburg-Vorpommerns, 37-60, Landesamt für Kultur und Denkmalpflege Mecklenburg-Vorpommern, 2014.

Michaelis, D. and Joosten, H.: Mire development, relative sea-level change, and tectonic movement along the Northeast-German Baltic Sea coast, Bericht der Römisch-Germanischen Kommission, 88, 101-134, 2007.

Price, D., Frei, R., Brinker, U., Lidke, G., Terberger, T., Frei, K., and Jantzen, D.: Multi-isotope proveniencing of human remains from a Bronze Age battlefield in the Tollense Valley in northeast Germany, Archaeol. Anthrop. Sci., https://doi.org/10.1007/s12520017-0529-y, 2017.

Richter, G.: Fernwirkung der litorinen Ostseetransgression auf tiefliegende Becken und Flußtäler, Eiszeitalter und Gegenwart, 19, 48-72, 1968.
Terberger, T. and Heinemeier, J.: Die Fundstelle im Tollensetal und ihre absolute Datierung, in: Tod im Tollensetal - Forschungen zu den Hinterlassenschaften eines bronzezeitlichen Gewaltkonfliktes in Mecklenburg-Vorpommern. Teil 1: Die Forschungen bis 2011, edited by: Jantzen, D., Orschiedt, J., Piek, J., and Terberger, T., vol. 50 of Beiträge zur Ur- und Frühgeschichte Mecklenburg-Vorpommerns, 101-116, Landesamt für Kultur und Denkmalpflege Mecklenburg-Vorpommern, 2014a.

Terberger, T., Dombrowsky, A., Dräger, J., Jantzen, D., and Lidke, G.: Professionelle Krieger in der Bronzezeit vor 3300 Jahren? Zu den Überresten eines Gewaltkonfliktes im Tollensetal, Mecklenburg-Vorpommern, in: Gewalt und Gesellschaft. Dimensionen der Gewalt in ur- und frühgeschichtlicher Zeit, edited by: Link, T. and Peter-Röcher, H., vol. 259 of Universitätsforschungen zur Prähistorischen Archäologie, 93-109, 2014b.

Terberger, T., Jantzen, D., Krüger, J., and Lidke, G.: Das bronzezeitliche Kampfgeschehen im Tollensetal - ein Großereignis oder wiederholte Konflikte?, in: Bronzezeitliche Burgen zwischen Taunus und Karpaten: Beiträge der Ersten Internationalen LOEWE-Konferenz vom 7. bis 9. Dezember 2016 in Frankfurt/M., edited by: Hansen, S. and Krause, R., vol. 319 of Universitätsforschungen zur prähistorischen Archäologie, 103123, 2018. 